\title{
Social Cooperatives of Disabled Persons in Poland: Postulates and Reality
}

\author{
Marzena Szabłowska-Juckiewicz*
}

\begin{abstract}
Disabled persons are at risk of exclusion from the labor market. Such exclusion may result in social marginalization or even social exclusion. Various legal instruments are used in attempts to prevent this phenomenon. Social cooperatives, classified as entities of the social economy, may play a significant role in the professional activation of the disabled. However, social cooperatives of disabled persons in Poland face barriers that limit their role in the process of the professional and social inclusion of disabled persons. Currently, the situation diverges considerably from the postulates formulated in justification for draft acts whose passage was to have contributed to the development of the cooperative activities of disabled persons.
\end{abstract}

Keywords: disabled person, social cooperative, social cooperative of disabled persons.

Submitted: 07.08.2015 | Accepted: 15.10.2015

\section{Spółdzielnie socjalne osób niepełnosprawnych w Polsce - postulaty a rzeczywistość}

Osoby niepetnosprawne sa zagrożone wykluczeniem z rynku pracy, które może prowadzić do marginalizacji spotecznej, a nawet - wykluczenia spotecznego. Wykorzystujac różnego rodzaju instrumenty prawne, podejmuje się próby przeciwdziatania temu zjawisku. Istotna role $w$ aktywizacji zawodowej osób niepetnosprawnych moga odgrywać spótdzielnie socjalne, zaliczane do podmiotów ekonomii spotecznej. Działalność spótdzielni socjalnych osób niepetnosprawnych $w$ Polsce napotyka jednak bariery, które sprawiaja, że rola spótdzielni socjalnych w procesie inkluzji zawodowej i spotecznej osób niepetnosprawnych jest ograniczona. Aktualna sytuacja $w$ sposób znaczacy odbiega od postulatów formutowanych $w$ uzasadnieniach projektów ustaw, których uchwalenie miało przyczynić się do rozwoju spótdzielczości osób niepetnosprawnych.

Słowa kluczowe: osoba niepełnosprawna, spółdzielnia socjalna, spółdzielnia socjalna osób niepełnosprawnych.

Nadesłany: 07.08.2015 | Zaakceptowany do druku: 15.10.2015

JEL: H53, H55, I18, J88, L26

\footnotetext{
Marzena Szabłowska-Juckiewicz, Ph.D. - Department of Labor Law, Faculty of Law and Administration, Nicolaus Copernicus University Toruń.

Mailing address: Department of Labor Law, Faculty of Law and Administration, Nicolaus Copernicus University Toruń, 3 W. Bojarskiego St., 87-100 Toruń; e-mail: m_sz@law.uni.torun.pl. Ministry of Science
and Higher Education Republic of Poland

The creation of the English-language version of these publications is financed in the framework of contract No. 768/P-DUN/2016 by the Ministry of Science and Higher Education committed to activities aimed at the promotion of education.
} 


\section{Introduction}

The "Declaration of Cooperative Identity" (1995) defines a cooperative as an autonomous association of people who voluntarily come together in order to satisfy common aspiration and economic, social, and cultural needs through co-ownership and democratic control of an enterprise. ${ }^{1}$ Such a definition has also been approved in Recommendation No. 193 of the International Labor Organization (ILO) of June 3, 2002 on the promotion of cooperatives. ${ }^{2}$

Cooperatives are enterprises whose activities, in principle, are aimed at achieving social goals. It is for this reason that they are listed among entities functioning in the area of the social economy (see Babis, 2013a, p. 21 as well as Hausner and Laurisz, 2008, p. 12). Topical literature stresses that, "the social economy and the social enterprises operating within its framework are a rational proposal and can be a significant component of activities on the labor market" (Babis, 2013, pp. 8-9 and similarly Borowska, 2014, p. 115). Cooperatives are the best example of this. The cooperative as a form of economic activity can play a key rope in active labor market policy in creating jobs for people under threat of social exclusion (Babis, 2013a, p. 24 and Blicharz, 2012, p. 204). To a great extent, this depends on its receiving of an appropriate legal framework and the development of best practice.

There can be no doubt that disabled persons are among those who experience difficulties on the labor market. In its Preamble (item $e$ ), the UN Convention of the Rights of Persons with Disabilities of December 13, 2006 (Journal of Laws of 2012, item 1169) stresses that disability can be a barrier to full participation in society. It is because of this that disabled persons are specifically vulnerable to social exclusion (Frąckiewicz, 2008, p. 15), including exclusion from professional life (Ratajczyk, 2005, p. 219). This being the case, the introduction of legislative solutions aimed at guaranteeing access to employment for disabled persons and making it possible for them to realize their right to work is becoming a pressing matter. Moreover, the Convention not only points to the need for promotion of employment for the disabled in the public and private sectors, but it also sees purpose in supporting cooperatives
(Article 27, Clause 1, items $g-h$ and item $f$ of the UN Convention of the Rights of Persons with Disabilities).

There are various types of cooperatives functioning in the realm of legal transaction. One form is the social cooperative. In Poland, the first regulations governing such cooperatives were introduced in 2004. The role of social cooperatives was boosted in connection with the passage in 2006 of separate legislation addressing the operations of such entities. "The social cooperative movement, in line with the intentions of the legislator, was intended to be a means of social and professional activation of people in danger of exclusion" (Ołdak, Syty, and Wojtanowski, 2010, p. 2010, and similarly Kempa, 2014, p. 184). Noting the difficulties of disabled persons in connection with undertaking professional activity, they became eligible to establish social cooperatives.

The objective of this paper is to show social cooperatives of people with disabilities as a legal form for social entrepreneurship. It looks at the regulations found in the Polish legal system and assesses them. This is accompanied by an attempt at answering questions relating to barriers that still occur in legal solutions in the activities of social cooperatives of disabled persons in Poland. The subject of analysis is also information on the functioning of social cooperatives of people with disabilities as contained in reports of the Council of Ministers and in the National Court Register (KRS). The current situation facing social cooperatives of people with disabilities in Poland is confronted with the postulates formulated in the justification for draft legislation whose passage was to have played a role in the development of the cooperative movement among the disabled and ultimately to lead to their professional and social inclusion.

\section{Genesis and Normative Regulation of the Activities of Social Cooperatives of Disabled Persons in Poland}

Prior to Poland's systemic transformation, disabled persons primarily found employment in work cooperatives, including cooperatives for invalids and cooperatives for the blind. Economic change that accompanied Poland's systemic transformation had a negative impact on the financial 
condition of such cooperatives. Moreover, topical literature indicates that "instead of granting cooperatives autonomy and independence, they were treated as a relicts of a bygone era designated for liquidation" (Babis, 2013, pp. 29-30).

In the wake of 1989, attempts were made in Poland to create an institutional-legal framework for a new system for professional rehabilitation and the employment of disabled persons that would take into account the new social and economic reality. An expression of action in this area was the passage of the Act of May 9, 1991 on the Employment and Professional Rehabilitation of Disabled Persons (Journal of Laws No. 46, Item 46, with subsequent amendments) and subsequently in the Act of August 27, 1997 on the Professional and Social Rehabilitation and Employment of Disabled Persons (unified text in the Journal of Laws of 2011, No. 127, item 721, with subsequent amendments). The latter legislation is still in force, but has been amended multiple times.

In 2004, new institutions made their appearance in the Polish professional rehabilitation and employment system for the disabled - i.e. social cooperatives. Changes were introduced into the Act of September 16, 1982 - The Cooperative Code (unified text in the Journal of Laws of 2003, No. 188, item 1848 , with subsequent amendments) pursuant to Article 127 of the Act of April 20, 2004 on the Promotion of Employment and Labor Market Institutions (Journal of Laws No. 99, item 1001, with subsequent amendments). Section V - "Social Cooperatives" was added to Title Two of Part One of that Act. "This modification failed to introduce substantial change, however. It primarily introduced a new form of the current work cooperative" (Godlewska-Bujok and Miżejewski, 2012, p. 12). As a side note, it should be remembered that disabled persons were only one of the categories entitled to form social cooperatives from the very beginning.

At present, principles of the functioning of social cooperatives in legal transactions are regulated by separate legislation - i.e. the Act of April 27, 2006 on Social Cooperatives (Journal of laws No. 94, item 651, with subsequent amendments). The justification to the draft indicates that it implements the assumptions of the Lisbon Strategy and is one of the elements of government policy aimed at limiting the phenomenon of social marginalization and exclusion. The argument for a need to create a separate act governing social cooperatives was that they can play an exceptionally important role in active social policy. What was stressed was that the goal of the legislation is the expansion of the institution of the social cooperative as well as the strengthening of its position on the labor market. Together with the legislation on social employment, it was intended to create a cohesive system of professional activation and employment for people in danger of social exclusion, including low-employability people (Parliamentary Paper No. 49).

Social cooperative legislation defines the principles for establishing, conducting business, merging, and liquidating social cooperatives. Article 1, Clause 2 of the Act on Social Cooperatives refers to the provisions of the Act of September 16, 1982 - The Cooperative Code (unified text in the Journal of Laws of 2013, No. 1443, item 1848, with subsequent amendments) with regard to matters it does not regulate. Regulations relating to social cooperatives may also be found in the Act of June 13, 2003 on Social Employment (unified text in the Journal of Laws of 2011, No. 43, item 225, with subsequent amendments), the Act of April 20, 2004 on the Promotion of Employment and Labor Market Institutions (unified text in the Journal of Laws of 2015, item 149, with subsequent amendments), the Act of April 24, 2003 on Public Service and Volunteer Service (unified text in the Journal of Laws of 2014, No. 1118, with subsequent amendments), and the Act of August 27, 1997 on the Professional and Social Rehabilitation and Employment of Disabled Persons (unified text in the Journal of Laws of 2011, No. 127 , item 721, with subsequent amendments).

The Polish legislator, in regulating the legal situation of social cooperatives, benefited from Finnish models. Social cooperatives have qualities of a company as well as of a nongovernmental organization (Godlewska-Bujok and Miżejewski, 2012, pp. 3 and 13). Their task is to combine the social integration of the excluded with the business and professional activities of their members, persons experiencing difficulties on the labor market (Blicharz, 2012, p. 201).

In the Polish legal system, there exists a special type of social cooperative hold- 
ing the status of a supported employment enterprise employer as understood by Article 28, Clause 1a of the Act on the Professional and Social Rehabilitation and Employment of Disabled Persons. Worth mentioning is the fact that supported employment enterprises are entities operating within the framework of the supported labor market.

\section{Social Cooperatives of Disabled Persons: Articles of Association}

Social cooperatives of disabled persons operate on the basis of the Act on Social Cooperatives and other legislation as well as on the basis of articles of association. ${ }^{3}$ Topical literature stresses that, "cooperative activities require the granting of articles of association" (Godlewska-Bujok 2012, p. 28). Pursuant to Article 6, $\S 1$ of the Cooperative Code, persons intending to establish a cooperative (the founders) ratify articles of association and confirm their ratification by signing them. This provision is also applicable in the case of social cooperatives of disabled persons.

Article 5 as well as regulations in other provisions of the Cooperative Code defines the necessary content of the articles of association (Gersdorf and Ignatowicz, 1985, p. 27 and Niedbała, 1994, p. 13). For its part, "the Act on Social Cooperatives contains paltry legal regulations regarding the content of the articles of association of social cooperatives" (Tylec, 2012, p. 189). This being the case, pursuant of Article 1 , Clause 1 of the Act on Social Cooperatives, it is the provisions of the Cooperative Code that should be applied in the case of the articles of association of social cooperatives.

The articles of association of social cooperatives should define:

1) The name with the addition of "Spó1dzielnia Socjalna" [Social Cooperative] and its registered office;

2) The subject of activities of the cooperative as well as its duration, if it is assumed that its founding is for a defined period of time;

3 ) Level of the entry contribution as well as the level and number of shares that a member is obligated to pledge, deadlines for payment and return and the effects of failure to contribute the share within the deadline, and in the event that the articles of association assume the contribution of more than one share it may define their upper limit;

4) The rights and responsibilities of members;

5) Principles and procedure for accepting members, terminating membership, barring members, and excluding members;

6) Principles for calling general assemblies, deliberations during such assemblies, and the passing of resolutions;

7) Principles and procedure for selecting and withdrawing members of the cooperative's bodies;

8) Principles for the division of balance sheet surpluses (general income) and the covering of cooperative losses. ${ }^{4}$

Moreover, the articles of association of a social cooperative should contain provisions, whose introduction is required by regulations of the Cooperative Code (e.g., Article 17 § 3-4) and the Act on Social Cooperatives (e.g., Article 11), making reference to the articles of association. This referring of legislative regulations to the articles of association is "an expression of the honoring by the legislator of the self-government of the cooperative" (Gersdorf and Ignatowicz, 1985, p. 25). Other provisions may also be included in the working of the articles of association. ${ }^{5}$

In drafting the wording of the articles of association of a social cooperative, special attention should be paid to the way in which the subject of activities of the cooperative is defined, including the type economic activity undertaken by the cooperative and activities for a fee and free of charge in the area of the social and professional reintegration of its members. The articles of association should also determine as to whether the cooperative shall conduct fee-based or free social and educational-cultural activities for its members and for the local community as well as public service activities as defined in the Act of April 24, 2003 on Public Service and Volunteer Service (Article 2 in connection with Article 8 of the Act on Social Cooperatives). Articles of association of social cooperatives also include detailed regulations relating to the rights and obligations of cooperative members that are the realization of legislative regulations. ${ }^{6}$ This practice should be considered fully justified.

As to the legal character of cooperative articles of association, views vary. There 
is no doubt that "most of its provisions pertain to the cooperative organizational system and relations among members of the cooperative" (Gersdorf and Ignatowicz, 1985, p. 26). The overriding view of representatives of the doctrine of the labor code is that "cooperative articles of association are not the only agreements binding the cooperatives and its members" (Florek, 2012, p. 42). The wording of Article 9 of the Labor Code gives occasion to the assumption that articles of association of social cooperatives of persons with disabilities (like the articles of association of work cooperatives) are considered in the category of autonomous (extra-legislative) sources of labor law. "For the cooperative and its members, the provisions of the articles of association are a source of law in the sense that certain obligations stem from them whose counterpart is the application of rights for the other party" (Florek, 2012, p. 42).

\section{Goals and Subject of Activities of Social Cooperatives of Disabled Persons}

A social cooperative of persons with disabilities is considered an entity of the social economy for which "in addition to economic goals, the social mission is of great significance. Profit is not an aim in and of itself, but a means to achieve social aims" (Babis, 2013, p. 11). What follows is that the establishing of a social cooperative has two fundamental goals: the common managing of a company and the inclusion of its members in professional and social life (Blicharz, 2012, p. 2005 and Staszewska, 2012 , p. 248). In the case of social cooperatives of persons with disabilities, the joint managing of a company is to lead to the professional and social inclusion of people with disabilities.

Areas of activity of the social cooperative have been listed in Article 4 of the Act on Social Cooperatives. For its part, the articles of association should give detail and clarify the subject of activities of the cooperative.

The status of social cooperatives is that of a business as understood by Article 4 of the Act on Freedom of Economic Activity (unified text in the Journal of Laws of 2013, item 672, with subsequent amendments). The Act on Social Cooperatives defines the general rule governing the undertaking of business activities by a social cooperative. Article 2, Clause 1 of the Act speaks of the conducting of a joint business based on the personal work of members. However, social cooperatives cannot limit themselves to conducting business operations. Pursuant to Article 2, Clause 2 of the Act on Social Cooperatives, they should provide a pubic service and work towards the professional reintegration of members. "Working for the social and professional reintegration of cooperative members is an obligatory task relating exclusively to cooperative members. It is one of the elements making up a social cooperative" (Godlewska-Bujok and Miżejewski, 2012, p. 19). Again, the managing of a common company based on the personal work of social cooperative members is not a target in and of itself. It serves to realize social goals - i.e. the social and professional reintegration of social cooperative members. What is made clear here, as is the case for other social economic entities, is the "primacy of activities catering to people while simultaneously taking care to achieve economic gain" (Izdebski and Małek 2007, p. 194).

Social cooperatives may also undertake social and educational activities for their members and for their local community as well as public service in the area of public tasks as defined in the Act of April 24, 2003 on Public Service and Volunteer Service pursuant to Article 2, Clause 3 of the Act on Social Cooperatives. The decision to conduct operations in this area has been left to the social cooperatives by the legislator. It may do so after having introduced the relevant provisions into its articles of association, as discussed in Article 2, Clause 3 of the Act on Social Cooperatives, or forego such operations (Godlewska-Bujok and Miżejewski, 2012, p. 21).

Also worth noting is the wording of Article 8, Clause 1 of the Act on Social Cooperatives. This provision establishes that statutory activities of social cooperatives in the area of social and professional reintegration of its members, social and educational-cultural activities for its members and their local community, and public service activities in the area of public tasks as defined in the Act of April 24, 2003 on Public Service and Volunteer Service is not 
economic activities as understood by the provisions of the Act of July 2, 2004 on Freedom of Economic Activity and may be undertaken as statutory activities for a fee or free of charge.

\section{Founders and Other Members of a Social Cooperative of Disabled Persons}

"The Polish social cooperative model is based on the possibility of such entities being formed exclusively by groups as defined in legislation" (Blicharz, 2012, p. 210). In line with Article 4, Clause 1 of the Act on Social Cooperatives, in principle, the founders and members of a social cooperative may be:

1) Unemployed persons as understood by Article 2, Clause 1, item 2 of the Act on the Promotion of Employment and Labor Market Institutions,

2) Persons in danger of social exclusion who have been indicated in Article 1, Clause 2, items 1-4, 6 and 7 of the Act on Social Employment, and

3 ) Disabled persons as understood by the provisions of the Act on Professional and Social Rehabilitation and the Employment of Disabled Persons.

Social cooperative founders are required to have full legal capacity, while members who are not founders may have only limited legal capacity (Article 5, Clause 4 of the Act on Social Cooperatives). Pursuant to Article $17 \S 1$ of the Cooperative Code, cooperative founders, signatories to the articles of association, become members of the cooperative at the moment of its registration. For their part, those who join the cooperative after its registration become members at the moment they are accepted by the cooperative. On the basis of references found in Article 1, Clause 2 of the Act on Social Cooperatives, this provision also applies to social cooperatives.

The legislator has introduced departures from the general rule that social cooperative founders and members can only be people as specified in Article 4, Clause 1 of the Act on Social Cooperatives. Persons other than those indicated in Article 4, Clause 1 of the Act on Social Cooperatives may be founders or may become members of social cooperatives assuming that their number is not greater than $50 \%$ of the total number of founders or mem- bers, respectively. Moreover, in the case of people acquiring membership in a social cooperative, the legislator has formulated a condition. The work of such persons as performed for the social cooperative must require special qualifications not held by other members of the cooperative. Church legal entities, nongovernmental organizations as understood by provisions governing public service and volunteer service, and local government entities may also establish social cooperatives and be there members (Article 4, Clause 2 and Article 5, Clauses 5-7 of the Act on Social Cooperatives).

The Act on Social Cooperatives introduces restrictions as to the number of founders and other members of the social cooperative. The number of social cooperative founders cannot be less than five if they are private individuals or two if they are legal entities. A social cooperative cannot have fewer than five or more than fifty members (Article 5, Clauses 1-2 of the Act on Social Cooperatives). The justification to the draft law indicates that solutions relating to numbers of cooperative founders and other members create "the possibility of common work for people who, alone, might have difficulties in opening and managing a business," on the one hand. On the other, it works against creating "huge cooperatives that loose their element of interpersonal collaboration, trust, and solidarity, and where member anonymity might appear" (Parliamentary Paper No. 49). There can be no doubt that the regulations found in Article 5 of the Act on Social Cooperatives foster the professional and social integration of cooperative members.

Disabled persons as understood by Article 1 of the Act of August 27, 1997 on the Professional and Social Rehabilitation and Employment of Disabled Persons (unified text in the Journal of Laws of 2011, No. 127, item 721, with subsequent amendments), regardless of their level of disability (Kempa, 2014, p. 185), are one of the categories of people entitled to establish a social cooperative. However, only disabled persons who have full legal capacity can establish a social cooperative (Article 4, Clause 1, item 3 of the Act on Social Cooperatives). At the same time, disabled persons with limited legal capacity can be members of social cooperatives (Article 5, Clause 4 of the Act on Social Cooperatives). 
Thus, in the case of disabled people establishing a cooperative or becoming members of one, general regulations relating to the founders and other cooperative members, including regulations limiting their allowable numbers, are applicable. The application of the latter has been excluded in a situation as discussed in Article 5, Clause 3 of the Act on Social Cooperatives. That provision states that a social cooperative that was established as a result of the transformation of a cooperative of invalids or a cooperative for the blind may have more than fifty members. This waiving of the rule limiting the allowable number of cooperative members seems justified in this case as no limits on allowable numbers of members are formulated with respect to cooperatives for invalids and for the blind. What follows is that a problem might appear upon the transformation of such cooperatives into social cooperatives in the form of the need to reduce the number of members.

"A key matter in the social cooperative movement is the empowerment of its members. People who establish a cooperative can feel responsible for the jobs they create" (Niedek, 2009, p. 16). Among the basic obligations of a social cooperative member is the duty to care for the good and development of the cooperative and to participate in the performance of its statutory tasks (Article $18 \S 5$ of the Cooperative Code, in connection with Article 1, Clause 2 of the Act on Social Cooperatives). As to the rights of social cooperative members, they specifically have the right to participate in the general assembly, elect and be elected to cooperative bodies, and to demand that the relevant cooperative bodies examine proposals regarding cooperative activities. Moreover, rights and obligations stemming from membership are equal for all members (Article 18 \& 1-2 of the Cooperative Code in connection with Article 1, Clause 2 of the Act on Social Cooperatives).

\section{Obligations and Powers of a Social Cooperative of Disabled Persons in the Area of Employment of Members and People Who are Not Cooperative Members}

Bearing in mind the social mission of social cooperatives, the legislator restricts the freedom of selection of employees by such entities. The legislative decision was to introduce regulations requiring social cooperatives to employ members and limiting the employment of people who are not cooperative members.

As is the case with work cooperatives, social cooperatives are encumbered with the obligation of employing their members as well as the equal subdivision among them of work (Blicharz, 2012, pp. 214 and 226). The employee status of a social cooperative member is defined by the provision of the Cooperative Code in connection with Article 12, Clause 1 of the Act on Social Cooperatives and by the Labor Code to the extent not regulated by those provisions. Additional employee rights of members of social cooperatives with decisions confirming their disability are defined in the Act on the Professional and Social Rehabilitation and Employment of Disabled Persons.

Pursuant to Article 12, Clause 1 of the Act on Social Cooperatives, the employment relationship between the social cooperative and its member is created on the basis of a cooperative employment agreement of a form as defined by Article 201 of the Cooperative Code. The current wording of Article 12, Clause 1 of the Act on Social Cooperatives was established on the basis of Article 1, item 7 of the Act of May 7, 2009 on the Modification of the Act on Social Cooperatives and on Changes to Other Acts (Journal of Laws No. 91, item 742). It was then that forms of employment other than a cooperative employment agreement were made possible, including through agreements for outwork, job contracts, and specific work contracts.

A social cooperative employing a member who has a disability confirmed by an official decision is obligated to guarantee that such a person is provided with the necessary rational modifications involving the introduction of changes or specific adaptations for the concrete situation of which the employer had been notified as needed due to the disability of the given person, if the undertaking of such modifications and adaptations does not encumber the employer with disproportionately high burdens. Such burdens are not disproportionate if they are compensated for to a sufficient degree by public funding (Article 23a, Clauses 1-2 of the Act on the Professional and Social Rehabilitation and Employment of Disabled Persons). It should be noted that an employer introducing rational modifications 
may specifically apply for the reimbursement of additional costs as well as for the reimbursement of the costs of equipping the work station through the resources of the National Disabled Persons Rehabilitation Fund (PFRON) on the basis of Articles 26 and 26e of the Act on the Professional and Social Rehabilitation and Employment of Disabled Persons, as appropriate.

Rational modifications in a work station are especially important in the case of the employment of persons considered to be disabled to a significant or moderate extent. In light of Article 4, Clause 1 of the Act on the Professional and Social Rehabilitation and Employment of Disabled Persons, it is possible to employ such people in a social cooperative that does not guarantee supported employment terms if the work station is adapted to the needs of the disabled person or if employment takes on the form of telework. An alternative for such people is employment in a social cooperative that has the status of a supported employment enterprise.

The legislator did not limit himself to the encumbering of social cooperatives with the obligation of employing their members, but also decided to introduce requirements restricting the right of a social cooperative to employ workers who are not cooperative members. Pursuant to Article 12, Clause 1a of the Act on Social Cooperatives, the total number of people as discussed in Article 4, Clause 1 (i.e. the unemployed, people in danger of social exclusion, and the disabled) cannot be less than $50 \%$ with respect to the total number of cooperative members and people employed by the social cooperative. ${ }^{7}$ Such a solutions should be deemed as being justified as the activities of social cooperatives should be aimed at the social and professional reintegration of people specified in Article 4, Clause 1 of the Act on Social Cooperatives, especially the disabled. The priority is to create jobs for people in danger of social and professional exclusion, not for people who do not face difficulties on the labor market.

\section{Support for the Activities of Social Cooperatives of Disabled Persons through Public Funding}

Bearing in mind the situation of persons entitled to establish a social cooperative, it is true that "without introducing legal and financial solutions supporting the initial period of activity and development of the established entities, the mere facilitating of the creation of social cooperatives remains insufficient" (Ołdak et al., 2010, p. 295). The Polish legislator has assumed various forms of support for the activities of social cooperatives of persons with disabilities using public funds, including the resources of the National Disabled Persons Rehabilitation Fund (PFRON), the Labor Fund (FP), the state budget, and local government entities as well as the European Social Fund. Funding may be sought during the establishing of the social cooperative as well as during its business operations.

A disabled person registered with the powiat (county level) employment office as being unemployed or seeking employment while not being employed may receive one-time financing from the National Disabled Persons Rehabilitation Fund (PFRON) as his or her contribution to the social cooperative. The amount is defined in an agreement concluded with the starosta (county manager), but it may not be greater than fifteen times the average wage, assuming that that person has not received nonreturnable public funding for this purpose previously (Article 12a of the Act on the Professional and Social Rehabilitation and Employment of Disabled Persons). Funding may be received for a first-time contribution or for another contribution if in line with a declaration by the applicant at least twelve months has elapsed as of that person ceasing to be a member of a social cooperative ( $\$ 2$, items $2-3$ of the Directive of the Minister of Labor and Social Policy of October 17, 2007 on Granting Disabled Persons Funding for Undertaking Economic or Agricultural Activity or as a Contribution for a Social Cooperative, unified text in the Journal of Laws of 2015, item 102).

The procedure for accessing funding from the National Disabled Persons Rehabilitation Fund (PFRON) is formalized. The application to receive funding for a contribution to a social cooperative should be filed with the starosta who is relevant with respect to the location where the disabled person is registered as being unemployed or seeking a job while not being employed. The application form is defined in the attachment to the directive. In the event of the application being 
approved, the starosta summons the applicant for negotiations on contractual terms. The transfer of funds to the bank account indicated in the application takes place within fourteen days as of the signing of the agreement between the starosta and the person requesting funding from the National Disabled Persons Rehabilitation Fund (PFRON) ( $\$ 4$, Clauses 1 and 5, $\S 5$, Clause 3 , and $\S 7$, Clause 1 of the Directive on Granting Disabled Persons Funding for Undertaking Economic or Agricultural Activity or as a Contribution for a Social Cooperative).

The contribution to be made to a social cooperative may also be financed through the resources of the Work Fund (FP). The starosta may designate money from the Work Fund for someone who is unemployed as well as for a graduate of a social integration center or of a social integration club, if the performance of business activities as entered into the register of business activities is not suspended (Article 46, Clause 1, item 2 and Article 46, Clause 1a of the Act of April 20, 2004 on the Promotion of Employment and Labor Market Institutions (Journal of Laws of 2015, No. 149, with subsequent amendments). The level of granted funds cannot exceed four times the average wage per one founder member of the social cooperative or three times the average wage per member joining a social cooperative after its creation. Detailed terms and the procedure for granting funds out of the Work Fund to someone who is unemployed are defined in the Directive of the Minister of Labor and Social Policy of April 23, 2012 on Granting Funding for Undertaking Economic Activity in Line with Principles as Defined for Social Cooperatives (unified text in the Journal of Laws of 2015, item 639). Funding form the Work Fund as discussed in $\S 2$, Clause 1 of that directive may be granted for the establishing of a social cooperative or for joining one, including the covering the cost of legal advice, consultations, and advisory services in connection with the undertaking of such activity.

Analysis of the regulations of the Directive on Granting Funding for Undertaking Economic Activity in Line with Principles as Defined for Social Cooperatives leads to the conclusion that the procedure for having a subsidy approved is extremely formalized. The obligatory wording of the applica- tion initiating the procedures is defined in $\S 3$ of the Directive, as are the certifications and declaration that must be attached. The fact that the legislator created the possibility of filing a single application in the case of unemployed persons establishing a social cooperative should be viewed as a positive thing.

Prerequisite to receiving funding from the Work Fund is not only approval of the application, but also the conclusion of an agreement between the starosta and the person requesting the assistance. In the case of unemployed persons establishing a social cooperative, the date of transfer of funding is defined in the agreement, where the deadline should fall between the date of the conclusion of the agreement and the start of economic activity ( $\$ 6$, Clause 3 of the Directive on Granting Funding for Undertaking Economic Activity in Line with Principles as Defined for Social Cooperatives). "Resources (pecuniary and non-pecuniary) for the launching of economic activity granted by the Work Fund are transferred to the social cooperative by the person requesting them in the form of a contribution. It is for this reason that the articles of association must define the procedure and manner of providing the contribution as well as the principles of its assessment" (Blicharz, 2012, p. 209).

It must not be forgotten that the granting of resources for the undertaking economic activity in line with principles as defined for social cooperatives is a labor market instrument that is optional in character. As to its use, "the starosta decides, bearing in mind Work Fund resources and their effectiveness" (Wrocławska, 2011, p. 305). Moreover, it should be noted that disabled persons interested in establishing a social cooperative as well as those intent on joining one receive funding from the Work Fund for undertaking economic activity very rarely (Malec, 2011, p. 166).

A comparison of Article 46, Clause 1, item 2 and Clause $1 \mathrm{a}$ of the Act on the Promotion of Employment and Labor Market Institutions and Article 12a Act on the Professional and Social Rehabilitation and Employment of Disabled Persons as well as the directive making these regulations concrete shows both similarities and differences. Firstly, resources from the National Disabled Persons Rehabilitation Fund (PFRON) may be applied for by disabled 
persons registered as being unemployed or seeking a job while not being employed. For its part, the Work Fund is available to persons whose status is that of being unemployed as well as graduates of social integration centers and social integration clubs. In the latter case, no certification of disability is required. Secondly, the maximum level of one-time funding as granted by the Work Fund and the National Disabled Persons Rehabilitation Fund (PFRON) is different. As to similarities, in both cases the procedure is formalized and requires security for the return of the funds. Pursuant to $\S 9$, Clause 1 of the Directive on Granting Funding for Undertaking Economic Activity in Line with Principles as Defined for Social Cooperatives, the form required for securing the repayment of the one-time resources received from the Work Fund for the establishing of a social cooperative or for joining one may be that of a pledge, a promissory note with aval, a bank guarantee, collateral, blocked funds on a bank account, or a notary act subjecting the debtor to recovery. Such forms are also specified in $\S 6$, Clause 2, item 2, letter $h$ of the Directive on Granting Disabled Persons Funding for Undertaking Economic or Agricultural Activity or as a Contribution for a Social Cooperative. Topical literature notes that the specified forms of security covering the return of funds granted by the Work Fund or the National Disabled Persons Rehabilitation Fund (PFRON) are "requirements that are difficult to meet by a disabled person" (Kempa, 2014, p. 190).

A significant form of support for the activities of already existing social cooperatives is the refunding of social security premiums out of Work Fund resources. This is done on the basis of an agreement concluded between the starosta for the location of the cooperative's registered offices (Blicharz, 2012, p. 231). The provisions of Article 12, Clause 3a of the Act on Social Cooperatives assumes the possibility of reimbursement of social security premiums for social cooperative members employed on the basis of an employment contract or on the basis of forms as defined in Article 20 of the Cooperative Code. Work Fund resources may be used to finance a part of the remuneration corresponding to the premium due from the employee for retirement, benefits, and accident insurance as well as the part of the employer's personnel costs corresponding to the premium due for the employee's retirement, benefits, and accident insurance. Such a refund is possible for a period of twenty-four months as of the data of employment and one-half that amount for a successive twelve months up to a level corresponding to the monthly premium as based on the minimum wage for work. It should be stressed that this reimbursement of premiums for social security, as was the case for subsidies for the commencement of economic activity, is a labor market instrument that is optional in character (Wrocławska 2011, s. 305).

The activities of a social cooperative may also receive direct support through the resources of the state budget or the resources of the budgets of local government entities, specifically by way of:

1) Subsidies,

2) Loans,

3) Guarantees,

4) Services or consultations in finance, accounting, economics, law, and marketing, and

5) Reimbursement of the costs of vetting. Support is provided as de minimis assistance by way of resolution of the relevant body of the local government entity or within the framework of a ministerial program appropriate by virtue of social welfare as defined in regulations governing social welfare for purposes connected with the development of social cooperatives. Subsidies and services or consultations in such areas as finance, accounting, economics, law, and marketing may be co-financed out of the funds of the European Social Fund (Article 15, Clauses 1-2 and Clause 7 of the Act on Social Cooperatives).

The various forms of support for the activities of social cooperatives are also free of any fees or taxes. Article 6, Clause 3 of the Act on Social Cooperatives states that social cooperatives do not have to pay any court fees for their application to be entered into the National Court Register (KRS) as well as for applications to change entries and fees for notification of such an entry in the Monitor Sadowy $i$ Gospodarczy [Court and Commercial Gazette]. In its turn, Article 17, Clause 1, item 43 of the Act of February 15, 1992 on Income Tax on Corporate Entities (unified text in the Journal of Laws of 2014, item 851, with subsequent amendments) states that the income of a cooperative used for the social 
and professional reintegration of members, in the part not charged as deductible expenses, is free of income tax on corporate entities. Moreover, the status of social cooperatives is that of an employer managing a supported employment enterprise benefiting from exemptions as defined in Article 31, Clauses 1-2 of the Act on the Professional and Social Rehabilitation and Employment of Disabled Persons.

When looking at the question of support for the activities of social cooperatives, worth mentioning are the social clauses found in public tenders. Pursuant to Article 22, Clause 2 of the Act of January 29, 2004 the Public Tender Code (unified text in the Journal of Laws of 2013, No. 907, with subsequent amendments), the ordering party may make the reservation in the tender announcement that the order may only be granted to a contactor employing workers, where over $50 \%$ are disabled as understood by regulations governing professional and social rehabilitation and the employment of disabled persons or the relevant regulations of the members states of the European Union or of the European Economic Area. In the description of the subject of the tender, the ordering party may define requirements relating to the performance of the order relating to the employment of: a) The unemployed or youth for the purpose of vocational training, as discussed in regulations governing the promotion of employment and labor market institutions,

b) Disabled persons, as discussed in regulations governing the professional and social rehabilitation and employment of disabled persons, and

c) Other persons than those described in items $a$ and $b$, as discussed in regulations governing social employment or in the relevant regulations of the members states of the European Union or of the European Economic Area (Article 29, Clause 4, item 1 of the Public Tender Code).

It is stressed that the social clause in public tenders is an instrument that may play a significant role in supporting the activities of social cooperatives (Malec, 2011, s. 160).

In conclusion, social cooperatives of disabled persons, in performing a public service (i.e. their activities involve the professional and social reintegration of disabled persons), can benefit from public funding. In assuming the criterion of "responsibility for public service," considering social cooperatives of disabled persons entities of public management is justified (compare with Kuźnik, 2005, pp. 70-71). Topical literature stresses that entities of public management "are and can only be organizations whose mission is work for the public interest and that are capable of operating in a novel manner causing the functioning of the organization as well as other sectors to simultaneously guarantee the achievement of their own goals as well as the public interest" (Fraczkiewicz-Wronka, 2010, p. 35). Moreover, it is pointed out that recent years have seen significant changes in the management of public service. "The essence of these changes is the shifting from a management style that is typical of the national, regional, and local levels that is hierarchical and bureaucratic (government) to a partnership (governance) based on collaboration among the various entities" (Frączkiewicz-Wronka, 2010a, p. 9). There can be no doubt that the noting of these changes and the development of an appropriate model for managing pubic service will facilitate the search for public funding by social cooperatives for disabled persons as well as their efficient utilization.

\section{The Activities of Social Cooperatives of Disabled Persons and Other Forms of Professional Activity of Disabled Persons in Poland: Information}

\subsection{The Professional Activity of Disabled Persons}

The average level of employment of disabled persons in the countries of the European Union is approximately $50 \% .8$ The figure is much lower for Poland. ${ }^{9}$

The economic activity rate of people with disabilities of working age in Poland over the years 2001-2002 and starting with the year 2005 amounted to over $25 \%$. Moreover, there was a successive growth in both the economic activity rate for people with disabilities and in the employment rate for people with disabilities of working age over the years from 2006 to 2012. The years 2013 and 2014 saw a small drop in the economic activity rate and in the employment rate for people with dis- 
abilities as compared with the previous year. ${ }^{10}$ In 2014 the economic activity rate for people with disabilities of working age reached a level of $27.1 \%$. For its part, the employment rate and unemployment rate amounted to $22.8 \%$ and $16.1 \%$, respectively. ${ }^{11} \mathrm{~A}$ total of 434,000 disabled persons had gainful employment in 2014. Of this figure, 346,000 were employed as salaried employees, 69,000 were self-employed and employers, while 18,000 provided help as family members. ${ }^{12}$

At the end of December of 2014, a total of 243,000 disabled persons were registered with the Subsidy and Reimbursement Services System (SODiR), managed by the National Disabled Persons Rehabilitation Fund (PFRON). The figure includes 103,6000 persons employed on the open labor market and 139,300 persons working in supported employment enterprises. In December of 2014, 23,971 disabled persons managing businesses filed for reimbursement of social security premiums. Moreover, 2,086 farmers with disabilities were entitled to receive reimbursement of social security premiums in the fourth quarter of $2014 .{ }^{13}$

\subsection{Activities of Social Cooperatives of Disabled Persons}

Pursuant to Article 20 of the Act on Social Cooperatives, the Council of Ministers was obligated to present a report by June 30,2008 on the effects of the Act as of the date of its coming into force to December 31, 2007. The Minister of Labor and Social Policy presented his "Report on the Implementation of Tasks of the Act of April 27, 2006 on Social Cooperatives" to the Speaker of the Sejm [Parliament] in June of 2008. The report calls attention to the development of the social cooperative movement in Poland. At the close of December of 2005 the National Court Register (KRS) had registered forty social cooperatives, while the figure at the end of December of 2007 was 139 . The activities of Regional Social Economy Funds and Social Cooperative Activity Support Center are listed among factors with an impact on the growth in the number of social cooperatives in Poland. It was noted that among social cooperatives, the majority were founded by groups of five. The economic activities undertaken by social cooperatives are concentrated in two areas: services $(88 \%$ of operating social cooperatives) and manufacturing (12\% of operating social cooperatives) (Parliamentary Paper No. 930).

Pursuant to Article 4, item 3 of the Act of August 19, 2011 on Modifications to the Act on Social Employment and Certain Other Acts (Journal of Laws No. 205, item 1211), The Act on Social Cooperatives received its Article 19a, which introduced a system of continuous monitoring of the activities of social cooperatives. Article 19a of the Act on Social Cooperatives encumbers of Council of Ministers with an obligation to provide the Sejm [Parliament] and Senate with information regarding the functioning of social cooperatives every two year, no later than on June 30 . This information is to be based on data provided to the minister responsible for social welfare by auditorial unions concerned with social cooperatives by December 30 of the year preceding the year for the submission of the information. Information regarding the functioning of social cooperatives has been submitted twice to date, for the 2010-2011 period (Parliamentary Paper No. 738) and the 2012-2013 period (Parliamentary Paper No. 3166).

There was further growth in the number of social cooperatives during the period encompassed by monitoring as dictated by Article 19a of the Act on Social Cooperatives (i.e. the years 2010-2011 and 20122013). A total of 276 social cooperatives had registered with the National Court Register (KRS) by 2010, the figure for 2011 was 425, with 615 for 2012, and 936 for 2013. Growth in the number of social cooperatives did not translate into proportional growth in public spending on supporting their operations. As to resources distributed by the Work Fund for the launching of operations in line with principles as defined for social cooperatives, it was only three times that the number of unemployed benefiting from this labor market instrument exceeded one hundred over one calendar year over the years 2005-2013. This was in 2010 (189 unemployed), 2012 (140 unemployed), and 2013 (104 unemployed). The largest subsidy amount for this purpose was achieved in 2010. It amounted to PLN 2,135,900. The number of beneficiaries and subsidy amount was even smaller in the area of resources provided by the National Disabled Persons Rehabilitation 
Fund (PFRON) for contributions to social cooperatives. Resources were provided for sixteen people in 2010, seventeen in 2011, forty-four in 2012, and twenty in 2013. The total figure for subsidies over those years amounted to PLN 465,905, PLN 435,704, PLN 1,077,130, and PLN 548,644, respectively. It should be noted that an instrument that was used only marginally in support for the activities of social cooperatives is the social clause in public tenders. In the year 2010 it was included in a mere $0.34 \%$ of the total number of public tenders. The situation was similar for successive years where the rate of orders including such a reservation amounted to $0.19 \%$ (2011), $0.14 \%$ (2012), and $0.23 \%$ (2013). ${ }^{14}$

It was the unemployed who were most often the founders of social cooperatives over the years 2010-2011 and 2012-2013. Persons with certified disabilities (including long-term unemployed) found employment in $43.9 \%$ of the social cooperatives (20122013). Most often, social cooperatives had five to nine members. The dominant form of employment was a cooperative employment contract, although job contracts and specific work contracts were also used to a relatively broad extent. 15

Most of the social cooperatives operated on a local or regional level over the monitored periods. As to business activity, social cooperatives were primarily involved in the rendering of services. Their operations usually encompassed multiple industries and trades. Among the basic benefits of the functioning of social cooperatives in legal transaction are the creation of jobs for people in danger of social exclusion (including the disabled) and the social and professional reintegration of their members. Studies conducted within the framework of the monitoring of the activities of social cooperatives have indicated that such entities have problems with both internal and external day-to-day operations, however. Specifically listed among the latter are a lack of understanding for social cooperatives as well as a an absence of interest on the part of local government, difficulties in procuring financing, and complex legal solutions. Most cooperative members are of the view that the system of normative acts regulating this area does not foster the development of social cooperatives. They point to a need for the creation of an institutional system supporting social coopera- tives as well as a database with information on possibilities for attracting funding by social cooperatives. What is seen as positive includes the extension of the period of social security reimbursement out of Work Fund resources, the ability to employ cooperative members using forms other than cooperative employment contracts, principles for employing people who are not cooperative members, and the possibility of applying simplified bookkeeping by social cooperatives. ${ }^{16}$

\section{Conclusions}

Social cooperatives of disabled persons are entities functioning within the framework of the social economy sector. The activities of social cooperatives of disabled persons are aimed at performing a public service, mainly the professional and social reintegration of people with disabilities. The achievement of such a goal through the managing of a common company based on the personal work of its members. It should be stressed that the conducting of economic activity and the generating of profits is not in this case a goal in and of itself.

Topical literature notes that, "the social economy is an answer to the escalation of social exclusion and the ineffectiveness of ways of fighting it to date" (Babis, 2013, p. 9). The promotion of the activities of social cooperatives of disabled persons is a part of that current. It is an expression of a striving for full integration of people with disabilities into society. The guaranteeing of employment for the disabled on the supported labor market is currently considered insufficient. The goal is to make it easier for disabled persons to take up employment on the open labor market, which facilitates more complete integration with society. The achieving of this target ushers in positive effects not only for disabled persons and their families, but also for the economy. People with disability cease being exclusively beneficiaries of social welfare, they pay taxes and participate in the financing of their social security premiums (to various extents depending on their legal form of employment).

Attention should also be called to the social aspects linked to the functioning of social cooperatives of disabled persons, especially cooperatives whose founders 
are private individuals. Social cooperatives are not "ordinary" employers. Disabled persons are tied to the social cooperative not only through their employment relationship, but also their membership. They participate in the management of the company. Employment in a social cooperative also creates potential for raising professional qualifications.

A closer look at the operations of social cooperatives of disabled persons in Poland could prove useful in identifying barriers they come up against. Encumbering the Government Plenipotentiary for Disabled Persons with an obligation to monitor the activities of social cooperatives of disabled persons seems justified. The reports prepared by the Council of Ministers on the activities of all social cooperatives in Poland can only be considered as being insufficient in this regard.

An argument in favor of supporting social cooperatives of disabled persons in Poland is also the fact that the Polish system of professional rehabilitation and employment of disabled persons is deemed to be relatively ineffective (Barczyński, 2009, p. 182 and Bartkowski et al., 2009, p. 9 and p. 17 and the following). In spite of the fact that the economic activity and the employment rates for disabled persons are successively rising in Poland, they continue to be significantly lower than the average for the European Union (Mańczak, 2010, p. 14 and Magnuszewska-Otulak, 2011, p. 28). Moreover, an ongoing problem in Poland is that the majority of disabled persons are employed on the supported labor market, in supported employment enterprises and in vocational development centers (Gąciarz, Giermanowska, and Sobiesiak, 2009, p. 12). Appreciating the potential of social cooperatives of disabled persons could be a starting point for modernization of the Polish system for professional rehabilitation and the employment of disabled persons as well as to improve its efficiency.

The normative regulation of the activities of social cooperatives of disabled persons in Poland is free of any major concerns. However, worth considering is if perhaps the procedures for granting funds from the National Disabled Persons Rehabilitation Fund (PFRON) and the Work Fund for contributions for social cooperative are not overly formalized. It seems that the undertaking of legislative efforts is also necessary with respect to ways of securing the return of funds granted by the National Disabled Persons Rehabilitation Fund (PFRON) and the Work Fund. Disabled persons who decide to establish or join a social cooperative face significant difficulties in meeting the requirements set by the legislator.

\section{Footnotes}

1 http://www.krs.org.pl/index.php?option=com content $\&$ view $=$ article $\&$ id $=43 \&$ Itemid $=29 \overline{9}$ (accessed on July 26, 2015).

2 http://www.mop.pl/doc/htlm/zalecenia/z 193. html (accessed on July 26, 2015).

3 See Article 2 of the Act of September 16, 1982 - The Cooperative Code (unified text in the Journal of Laws of 2013, No. 1443, with subsequent amendments) in connection with Article 1, Clause 2 of the Act of April 27, 2006 on Social Cooperatives (Journal of Laws No. 94, item 651, with subsequent amendments).

4 See Article 5, Clause 1 of the Act of September 16, 1982 - The Cooperative Code (unified text in the Journal of Laws of 2013, No. 1443, with subsequent amendments) in connection with Article 1, Clause 2 and Article 3 of the Act of April 27, 2006 on Social Cooperatives (Journal of Laws No. 94, item 651, with subsequent amendments)

5 See Article 5, Clause 2 of the Act of September 16, 1982 - The Cooperative Code (unified text in the Journal of Laws of 2013, No. 1443, with subsequent amendments) in connection with Article 1, Clause 2 of the Act of April 27, 2006 on Social Cooperatives (Journal of Laws No. 94, item 651, with subsequent amendments).

6 For example, see the Articles of Association of the PROMYK Social Cooperative (http:// wtzgoszkow.pl/wp-content/uploads/2014/03/ Statut-aktualnyap\%C3\%B3ldzielmnia-Promyk. pdf, accessed on August 4, 2015), the Articles of Association of the OPOKA Social Cooperative (http:/opokas.pl/wp-content/uploads/2011/05/ STATUT.pdf, accessed on August 4, 2015), the Articles of Association of the Z BRZUCHA KOJOTA Social Cooperative (http://www. zbrzuchakojota.pl/statut.pdf, accessed on August 4, 2015), and the Articles of Association of the FLOW Social Cooperative (http://www.flowfood. pl/wp-content/uploads/2014/03/Statut-FLOWSp\%C3\%B3\%C5\%82dzielni-Socjalnej.pdf, accessed on August 4, 2015).

7 The regulation found in Article 12, Clause 1a of the Act of Social Cooperatives was added by way of the Act of May 7, 2009 on the Modification to the Act on Social Cooperatives and on Changes to Other Acts (Journal of Laws No. 91, item 742). 
8 Communication from the Commission to the European Parliament, the Council, the European Economic and Social Committee and the Committee of the Regions of November 15, 2010 on the European Disability Strategy 2010-2020: A Renewed Commitment to a Barrier-Free Europe, COM/2010/636.

9 For a broader discussion see the "Analiza sytuacji osób niepełnosprawnych w Polsce i Unii Europejskiej" [Analysis of the situation of disabled persons in Poland and the European Union], a report prepared within the framework of the "Zatrudnienie osób niepełnosprawnych - perspektywy wzrostu" [The employment of disabled persons: Perspectives for growth] Project, which was co-financed by the National Disabled Persons Rehabilitation Fund (PFRON), E. Kryńska, Scientific Editor, developed by I. Kukulak-Dolata and M. Sobocka-Szczapa, Warsaw, 2013, p. 39, www.watchdogpfron.pl/wpcontent/uplouds/2014/03/Krynska-Sytuacja-ON. pdf (accessed on September 18, 2015).

10 Central Statistical Office of Poland - Labor Force Survey (GUS BAEL) - Activity of people with disabilities over the years 1993 to the 1st quarter of 2015, www.niepelnosprawni.gov. $\mathrm{pl} / \mathrm{p}, 81$,bael (accessed on September 18, 2015).

11 Central Statistical Office of Poland - Labor Force Survey (GUS BAEL) - Average yearly data for the year 2014 for people with disabilities of working age, http://www.niepelnosprawni. gov.pl/p,80,rynek-pracy (accessed on September 18, 2015).

12 Central Statistical Office of Poland - Labor Force Survey (GUS BAEL) - Number of people working with an employed status (average yearly and quarterly data), www.niepelnosprawni.gov. $\mathrm{pl} / \mathrm{p}, 81$,bael (accessed on September 18, 2015)

13 PFRON data, www.niepelnosprawni.gov.pl/p,83, sodir-pfron (accessed on September 18, 2015).

14 Based on information found in Parliamentary Paper No. 738 and Parliamentary Paper No. 3166. 15 Ibidem.

16 Ibidem.

\section{References}

Analiza sytuacji osób niepetnosprawnych $w$ Polsce $i$ Unii Europejskiej [Analysis of the situation of disabled persons in Poland and the European Union]. A report prepared within the framework of the Zatrudnienie osób niepetnosprawnych - perspektywy wzrostu [The employment of disabled persons: Perspectives for growth] Project. Co-financed by the National Disabled Persons Rehabilitation Fund (PFRON), E. Kryńska (ed.), developed by I. Kukulak-Dolata and M. Sobocka-Szczapa. Warsaw, 2013. Retrieved from: www.watchdogpfron.pl/ wp-content/uplouds/2014/03/Krynska-Sytuacja-ON pdf (18.09.2015).
Babis, H. (2013). Wprowadzenie [Introduction]. In: $\mathrm{H}$. Babis (ed.). Zarzadzanie podmiotami ekonomii spotecznej [Managing social economy entities]. Szczecin.

Babis, H. (2013a). Rodzaje podmiotów ekonomii społecznej [Types of entities in the social economy] (Chapter 2). In: H. Babis (ed.), Zarzadzanie podmiotami ekonomii spotecznej [Managing social economy entities]. Szczecin.

Blicharz, J. (2012). Ustawa o dziatalności pożytku publicznego $i$ o wolontariacie. Ustawa o spótdzielniach socjalnych. Komentarz [The Act on Public Service and Volunteer Service and the Act on Social Cooperatives: Commentary]. Warsaw: LEX a Wolters Kluwer business.

Barczyński，A. (2009). Skuteczność polskiego modelu aktywizacji zawodowej w warunkach gospodarki rynkowej [The effectiveness of the Polish model of vocational activation in a market economy]. In: B. Gaciarz and E. Giermanowska (eds.), Zatrudniajac niepetnosprawnych. Wiedza, opinie $i$ doświadczenia pracodawców [Employing disabled persons: Employer knowledge, opinions, and experience]. Warsaw.

Bartkowski, J., Gąciarz, B., Giermanowska, E. and Sobiesiak, P. (2009). Pracodawcy o zatrudnianiu osób niepetnosprawnych [Employers on the employing of disabled persons]. Warsaw.

Borowska, A. (2014). Ekonomia i przedsiebiorczość społeczna - charakterystyka [The social economy and social entrepreneurship: Characteristics] In: P. Ucieklak-Jeż (ed.), Wspótczesne problemy spotecznej gospodarki rynkowej [Contemporary questions of the social market economy] Częstochowa.

Florek, L. (2012). Prawo pracy [Labor law]. Warsaw: C.H. Beck.

Frąckiewicz, L. (2008). Niepełnosprawni - wykluczeni i osamotnieni [The disabled: Excluded and alone]. In: L. Frąckiewicz (ed.), Przeciw wykluczeniu społecznemu osób niepetnosprawnych [Against the social exclusion of disabled persons]. Warsaw: ILSS

Frąckiewicz-Wronka, A. (2010). Nowe zarządzanie publiczne jako praktyczne i teoretyczne ramy odniesienia dla lokalnej polityki społecznej [New public directives as practical and theoretical frameworks for local social policy]. In: A. FrączkiewiczWronka (ed.), Partnerstwo lokalne jako strategia rozwiazywania problemów społecznych [Local partnerships as a strategy for solving social problems]. Katowice.

Frąckiewicz-Wronka, A. (2010a). Wstep [Introduction]. In: A. Frączkiewicz-Wronka (ed.), Partnerstwo lokalne jako strategia rozwiazywania problemów spotecznych [Local partnerships as a strategy for solving social problems]. Katowice. 
Gonciarz, B., Giermanowska, E. and Sobiesiak, P. (2009). Wprowadzenie. Postawy pracodawców a polityka integracji osób niepełnosprawnych [The position of employers and disabled person integration policy: Introduction]. In: B. Gąciarz and E. Giermanowska (eds.), Zatrudniajac niepetnosprawnych. Wiedza, opinie $i$ doświadczenia pracodawców [Employing disabled persons: Employer knowledge, opinions, and experience]. Warsaw.

Gersdorf, M. and Ignatowicz, J. (1985). Prawo spótdzielcze. Komentarz [Cooperative law: Commentary]. Warsaw: Wydawnictwo Prawnicze, Wydawnictwo Spółdzielcze.

Godlewska-Bujok, B. and Miżejewski, C. (2012). Ustawa o spótdzielniach socjalnych. Komentarz [The Act on social cooperatives: Commentary]. Warsaw: ZWP MPiPS

Hausner, J. and Laurisz, N. (2008). Czynniki krytyczne tworzenia przedsiębiorstw społecznych. Przedsiębiorstwo społeczne. Konceptualizacja [Critical factors in creating social enterprises: Conceiving the social enterprise]. Przedsiębiorstwa spoteczne $w$ Polsce. Teoria $i$ praktyka [Social enterprises in Poland: Theory and practice]. Cracow.

Izdebski, H. and Małek, M. (2007). Prawne formy przedsiębiorczości społecznej w Polsce [Lega forms for social entrepreneurship in Poland]. In T. Kaźmierczak and M. Rymsza (Editors). Kapitat spoteczny. Ekonomia społeczna [Social capital: Social economy]. Warsaw.

Kempa, M. (2014). Spółdzielnie socjalne osób niepełnosprawnych [Social cooperatives of disabled persons]. In: A. Giedrewicz-Niewińska and M. Szabłowska-Juckiewicz (Editors, Part III, Chapter 7), Zatrudnianie osób niepetnosprawnych. Regulacje prawne [Employing the disabled: Legal regulations]. Warsaw: Difin.

Kuźnik, F. (2005). Stare i nowe koncepcje zarządzania publicznego w strukturach samorządu terytorialnego [Old and new public management concepts in local government structures]. In B. Kożuch and T. Markowski (Eds., Part I, Chapter 4$), Z$ teorii $i$ praktyki zarzadzania publicznego [From the theory and practice of public management]. Białystok.

Magnuszewska-Otulak, G. (2011). Bariery aktywności zawodowej osób niepełnosprawnych [Barriers to the professional activity of the disabled]. In: J. Plak (ed.), Osoby niepetnosprawne. Szanse i zagrożenia godnego funkcjonowania w spoteczeństwie [Disabled persons: Opportunities and threats to dignified functioning in society]. Warsaw.
Malec, K. (2011). Spółdzielnie socjalne osób niepełnosprawnych - dobre praktyki [Social cooperatives of disabled persons: Best practice]. Spótdzielnia socjalna osób niepetnosprawnych. Poradnik [Social cooperatives of disabled persons: A manual]. Warsaw.

Mańczak, M. (2010). Między Polską a krajami Uni Europejskiej [Between Poland and the countries of the European Union]. Niepetnosprawność $i$ Rehabilitacja [Disability and rehabilitation], 1.

Niedbała, Z. (1994). Statut w świetle znowelizowanego prawa spółdzielczego [Articles of association in light of the amended Cooperative Code] Poznań: PDW ŁAWICA.

Niedek, M. (2009). Spótdzielnie socjalne dla osób niepetnosprawnych - w kierunku lepszych rozwiazan prawnych [Social cooperatives of disabled persons: Towards better legal solutions]. Materials from a conference organized by the Komisja Samorządu Terytorialnego i Administracji Państwowej [Local Government and State Administration Commission] and the Fundacja Gmin Polskich [Polish Borough Foundation], April 16, 2008. Warsaw.

Ołdak, M., Syty, M. and Wojtanowski, G. (2010) Funkcjonowanie ustawy o spółdzielniach socjalnych. Wnioski i rekomendacje [The functioning of the Act on Social Cooperatives: Conclusions and recommendations]. Spótdzielnie socjalne. Skuteczny mechanizm walki $z$ wykluczeniem spotecznym czy ślepa uliczka [Social cooperatives: Efficient mechanisms for fighting social exclusion or a dead end?]. Poznań.

Ratajczyk, W. (2005). Osoby niepełnosprawne a wykluczenie społeczne - bariery dostępu do pracy [The disabled and social exclusion: Barriers to access to employment]. In: L. Frackiewicz (ed.), Wykluczenie spoteczne [Social exclusion]. Katowice: Wydawnictwo Akademii Ekonomicznej im. Karola Adamieckiego.

Staszewska, E. (2012). Środki prawne przeciwdziałania bezrobociu [Legal measures against unemployment]. Warsaw: LEX a Wolters Kluwer business.

Tylec, G. (2011). Statut spótdzielni i jego kontrola $w$ postępowaniu o wpis do Krajowego Rejestru Sadowego [Cooperative articles of association, their monitoring, and procedures for entry onto the National Court Register (KRS)]. Warsaw: Difin.

Wrocławska, T. (2011). In: Z. Góral (ed.), Ustawa o promocji zatrudnienia $i$ instytucjach rynku pracy. Praktyczny komentarz [The Act on the Promotion of Employment and Labor Market Institutions: Practical comments]. Warsaw: LEX a Wolters Kluwer business. 